\title{
HUBUNGAN ANTARA KONFLIK PERAN DAN AMBIGUITAS PERAN DENGAN KINERJA PERAWAT WANITA DI RSUD SUNGAI DAREH DHARMASRAYA
}

\author{
Sepda Dwi Putri , Harri Kurniawan \\ Universitas Putra Indonesia "YPTK" Padang, \\ email: sepdadwi17@gmail.com, arikkurniawan17@gmail.com
}

\begin{abstract}
This study aims to determine the relationship between role conflict and role ambiguity with the performance of female nurses in Sungai Dareh Dharmasraya Hospital. The independent variables in this study are role conflict and role ambiguity and the dependent variable is performance. The measuring instrument used in this study is the scale of role conflict, role ambiguity scale, and scale of performance. The sampling technique in this study used atechnique saturated sampling. The sample in this study were 70 female nurses in Sungai Dareh Dharmasraya Hospital. Validity and reliability test in this study usingtechnique Alpha Cronbach. The results of the validity coefficient on the movable role conflict scale from $r_{i x}=0.405$ to $r_{i x}=0.817$ with the reliability coefficient $\alpha=0.945$ while on the moving role ambiguity scale from $r_{i x}=0.349$ to $r_{i x}=0.945$ with the reliability coefficient $\alpha=0.971$ and at the moving performance scale from $r_{i x}=0.381$ to $r_{i x}=0.774$ with the reliability coefficient $\alpha=0.943$. Based on data analysis, the value of the correlation between role conflict and performance was -0.439 with a significance level of 0.000 and the correlation value between role ambiguity and performance was -0.310 with a significance level of 0.009 and the correlation value between role conflict and role ambiguity simultaneously with performance of 0.461 with significance level 0,000 which means the hypothesis is accepted. This shows that there is a significant relationship between role conflict and role ambiguity with the performance of female nurses in Sungai Dareh Dharmasraya Hospital.
\end{abstract}

Keywords: Role Conflict, Role Ambiguity, Performance

\begin{abstract}
ABSTRAK
Penelitian ini bertujuan untuk mengetahui hubungan antara konflik peran dan ambiguitas peran dengan kinerja perawat wanita di RSUD Sungai Dareh Dharmasraya. Variabel bebas dalam penelitian ini adalah konflik peran dan ambiguitas peran dan variabel terikat adalah kinerja. Alat ukur yang digunakan dalam penelitian ini adalah skala konflik peran, skala ambiguitas peran, dan skala kinerja. Teknik pengambilan sampel dalam penelitian ini menggunakan teknik sampling jenuh. Sampel dalam penelitian ini adalah 70 orang perawat wanita di RSUD Sungai Dareh Dharmasraya. Uji validitas dan reliabilitas pada penelitian ini menggunakan teknik Alpha Cronbach. Hasil koefisien validitas pada skala konflik peran bergerak dari $r_{i x}=0,405$ sampai dengan $r_{i x}=0,817$ dengan koefisien reliabilitas $\alpha=0,945$ sedangkan pada skala ambiguitas peran bergerak dari $r_{i x}=0,349$ sampai dengan $r_{i x}=0,945$ dengan koefisien reliabilitas $\alpha=0,971$ dan pada skala kinerja bergerak dari $r_{i x}=0,381$ sampai dengan $r_{i x}=0,774$ dengan koefisien reliabilitas $\alpha=0,943$. Berdasarkan analisis data, diperoleh nilai korelasi antara konflik peran dengan kinerja sebesar -0,439 dengan taraf signifikansi 0,000 dan nilai korelasi antara ambiguitas peran dengan kinerja sebesar -0,310 dengan taraf signifikansi 0,009 serta nilai korelasi antara konflik peran dan ambiguitas peran secara bersamaan dengan kinerja sebesar 0,461 dengan taraf signifikansi 0,000 yang berarti hipotesis diterima. Hal ini menunjukkan bahwa ada hubungan yang signifikan antara konflik peran dan ambiguitas peran dengan kinerja perawat wanita di RSUD Sungai Dareh Dharmasraya.
\end{abstract}

\section{Kata Kunci : Konflik Peran, Ambiguitas Peran, Kinerja}




\section{PENDAHULUAN}

Kinerja pegawai adalah hasil kerja secara kualitas, kuantitas dan ketepatan waktu yang dicapai oleh seorang pegawai dalam melaksanakan serta menjalankan tugasnya sesuai dengan tanggung jawab yang diberikan kepadanya dan tidak hanya dipengaruhi oleh kemampuan dan keahliannya dalam bekerja (Mangkunegara dalam Yasa, 2017) ${ }^{[16]}$. Menurut Habibullah dan Apriyani (dalam Yasa, 2017) ${ }^{[16]}$ ada beberapa faktor-faktor yang mempengaruhi tingkat kinerja pegawai yaitu stres kerja yang ditimbulkan oleh konflik peran, ambiguitas peran dan karakteristik tugas. Dengan mempertimbangkan peran SDM dalam memberikan pelayanan kepada masyarakat khususnya dibidang kesehatan maka SDM menjadi ujung tombak organisasi terkait dengan adanya indikasi dimana konflik peran dan ambiguitas peran tertentu akan berdampak pada kinerja pegawai.

Kinerja pada perawat merupakan faktor yang sangat penting bagi suatu rumah sakit. Kinerja sebagai perwujudan perilaku kerja seorang perawat yang ditampilkan sebagai prestasi kerja sesuai dengan peranannya dalam sebuah rumah sakit dalam jangka waktu tertentu. Hal ini dikarenakan kinerja perawat sebagai penentu keberhasilan serta kelangsungan hidup rumah sakit. Dalam setiap organisasi, manusia merupakan salah satu komponen yang sangat penting dalam menghidupkan organisasi tersebut. Hal ini harus didukung dengan kinerja yang baik pula karena tanpa kinerja yang baik, organisasi tidak akan mencapai tujuannya (Mangkunegara dalam Lumingkewas dkk, 2015) ${ }^{[9]}$.

World Health Organization (WHO) melaporkan bahwa ada lebih dari 9 juta perawat dan bidan di 141 negara. Hal ini menjelaskan bahwa perawat dibandingkan dengan disiplin ilmu lainnya, profesi perawat memegang peranan sangat besar dalam bidang pelayanan kesehatan. Persatuan Perawat Nasional Indonesia (PPNI) mengungkapkan sebanyak 50,9\% perawat Indonesia yang bekerja sering merasa pusing, lelah, kurang ramah, kurang istirahat akibat kondisi kerja serta penghasilan yang tidak memadai (Revalicha dalam Lumingkewas dkk, 2015) [9].

Kreitner dan Kinicki (dalam Yasa, 2017) ${ }^{[16]}$, konflik peran adalah orang-orang memiliki pengharapan yang saling bertentangan atau tidak konsisten. Luthans (dalam Yasa, 2017) ${ }^{[16]}$ mengatakan bahwa seseorang akan mengalami konflik peran jika seseorang memiliki dua peran atau lebih yang harus dijalankan pada waktu yang bersamaan. Nurqamar (dalam Yasa, 2017) ${ }^{[16]}$ dengan konflik peran yang tinggi dirasakan oleh seorang karyawan atau pegawai akan mengakibatkan timbulnya perasaan cemas, takut, tegang di dalam mengambil suatu pekerjaan dan akan berdampak kepada penurunan tingkat kinerja. Kurang berfungsinya peran diantaranya adalah konflik peran dan ketidakpastian peran, hal ini terjadi dikarenakan terlalu banyaknya tuntutan dalam pekerjaan. Akibanya perawat mengalami penurunan tingkat kinerja, meningkatnya ketidakpuasan pada pekerjaan, munculnya kecemasan, munculnya ketegangan dan keinginan keluar dari pekerjaan.

Selain permasalahan konflik peran, faktor lain yang menyebabkan penurunan kinerja ialah ambiguitas peran, hal ini dapat terjadi ketika harapan, tujuan, tanggung jawab seorang karyawan belum jelas dirancang. Oleh karena itu, karyawan menjadi ambivalen untuk memprediksi reaksi atasan mereka untuk tugas-tugas mereka sebagai "keberhasilan" atau sebagai "kegagalan". Ambiguitas peran pada pekerja dapat terjadi ketika individu tidak memiliki definisi yang jelas tentang harapan pada peran mereka dan metode yang jelas untuk menyelesaikan tugas-tugas pekerjaan mereka (Habibullah dan Apriyani dalam Yasa, 2017) ${ }^{[16]}$.

Berdasarkan hasil observasi dan wawancara yang didapat dari kepala perawat RSUD Sungai Dareh. Kepala perawat RSUD Sungai Dareh mengeluhkan terdapat beberapa perawat yang performa kerjanya menurun, dimana para perawat sebelumnya memiliki kinerja yang bagus, namun dengan adanya beberapa peran yang harus dijalankan menyebabkan performa kerjanya menjadi menurun, misalnya perawat yang bertugas dibagian pelayanan harus merangkap juga dibagian rekam medis diker'123456enakan kurangnya staf pada bagian rekam medis untuk mencatat administrasi pasien. Kondisi tersebut tidak hanya terkait dengan peran mereka sebagai perawat. Kepala perawat mengemukakan kurang maksimalnya pekerjaan yang 
dilakukan perawat bukan hanya disebabkan oleh pekerjaan yang mereka jalani sebagai perawat di rumah sakit, tetapi terdapat pekerjaan yang seharusnya lebih dominan dikerjakan oleh mereka yaitu sebagai seorang ibu. Kepala perawat mengungkapkan rata-rata sebagian besar perawat di RSUD Sungai Dareh merupakan perawat yang sudah berkeluarga, dengan bertambahnya tugas mereka sebagai perawat di rumah sakit, para perawat sering mendapatkan protes dari anak-anak, kerena merasa kurang mendapatkan perhatian, kasih sayang, dan waktu dari ibunya. Hal-hal inilah yang menyebabkan para perawat memberikan pelayanan yang kurang maksimal.

RSUD Sungai Dareh merupakan rumah sakit yang termasuk dalam tipe D, menurut Permenkes RI Nomor 340/MENKES/PER/III/2010 mengatur tentang perbandingan jumlah perawat dengan tempat tidur yaitu $2: 3$ atau $1: 1,5$ yang artinya 2 perawat menangani 3 tempat tidur atau 1 perawat menangani 1,5 tempat tidur. Tidak adanya kejelasan tentang berapa banyak jumlah pasien yang harus ditangani, membuat perawat RSUD Sungai Dareh mengalami ambiguitas peran dimana perawat mengerjakan tugas melebihi tanggung jawabnya, disatu sisi perawat bertanggung jawab terhadap tugas fisik, administratif dari instansi tempat ia bekerja, menghadapi kecemasan, keluhan dan mekanisme pertahanan diri pasien yang muncul akibat sakit yang dialaminya, disisi lain perawat juga selalu dituntut untuk tampil sebagai figur yang dibutuhkan oleh pasiennya, yang dapat bersimpati, selalu perhatian, fokus dan hangat kepada pasien. Para perawat merasa kesulitan untuk menyesuaikan peran di dalam rumah sakit, ketika perawat dituntut untuk bisa berhadapan dengan segala macam pekerjaan walaupun perawat tersebut kurang mempunyai kemampuan dibanding lain disatu sisi lainnya. Perawat memegang tanggung jawab yang diberikan oleh atasan, namun terkadang karena suatu hal perawat tersebut juga harus bertanggung jawab dengan hal yang lainnya di dalam rumah sakit secara bersamaan, hal inilah yang dirasa oleh para perawat mengalami ketidakjelasan peran karena pekerjaan yang dikerjakan tidak sesuai dengan job description mereka.

\section{LANDASAN TEORI Kinerja}

Kinerja adalah kesediaan seseorang atau kelompok orang untuk melakukan sesuatu kegiatan dan menyempurnakannya sesuai dengan tanggung jawabnya dengan hasil seperti yang diharapkan (Rivai dan Mulyadi dalam Sorongan dkk, 2015) ${ }^{[13]}$. Benardin dan Russel (dalam Priansa, 2017) ${ }^{[11]}$ menyatakan bahwa kinerja merupakan hasil yang diproduksi oleh fungsi pekerjaan tertentu atau kegiatan pada pekerjaan tertentu selama periode waktu tertentu. Hasil kerja tersebut merupakan hasil kemampuan, keahlian, dan keinginan yang dicapai. Milkovich dam Boudreau dalam Priansa, 2017) ${ }^{[11]}$ menyatakan bahwa kinerja adalah tingkat pegawai melaksanakan pekerjaannya sesuai dengan syarat-syarat yang telah ditentukan.

\section{Dimensi Kinerja Pegawai} sebagai berikut:

Wirawan (2009) ${ }^{[15]}$ mengelompokkan dimensi kinerja pegawai menjadi tiga, yaitu

a. Hasil kerja

Kuantitas dan kualitas hasil kerja pegawai dalam melaksanakan pekerjaannya. Hasil kerja dalam bentuk barang dan jasa yang dapat diukur jumlah atau kuantitas dan kualitasnya.

b. Perilaku kerja

Ketika berada ditempat kerja dan melaksanakan pekerjaannya, pegawai melakukan dua jenis perilaku yaitu perilaku kerja dan perilaku pribadinya.

c. Sifat pribadi yang ada hubungannya dengan pekerjaan

Sifat pribadi yang diperlukan oleh seorang pegawai dalam melaksanakan pekerjaannya.

\section{Konflik Peran}

Menurut Schemerhorn dkk (dalam Ekawarna, 2018) ${ }^{[6]}$ konflik peran dapat terjadi ketika harapan seseorang atau lebih dari anggota kelompok memperoleh peran yang tidak sesuai. Robbins (dalam Sorongan dkk, 2015) ${ }^{[13]}$ mendefinisikan konflik sebagai sebuah proses yang 
dimulai ketika satu pihak memiliki persepsi bahwa pihak lain telah memengaruhi secara negatif, sesuatu yang menjadi perhatian dan kepentingan pihak pertama.

Menurut Nirman (dalam Nur dkk, 2016) ${ }^{[10]}$ konflik peran adalah adanya ketidakcocokan antara harapan-harapan yang berkaitan dengan suatu peran. Konflik peran merupakan suatu hasil dari ketidakkonsistenan antara tuntutan peran dengan kebutuhan, nilainilai individu dan sebagainya.

\section{Indikator Konflik Peran}

Yang dkk (dalam Junita, 2011) ${ }^{[7]}$ mengidentifikasikan konflik peran menjadi beberapa indikator yaitu:

\section{a. Time based conflict}

Waktu yang dibutuhkan untuk menjalankan salah satu tuntutan (individu dalam pekerjaan) dapat mengurangi waktu untuk menjalankan tuntutan lainnya (pekerjaan atau individu).

b. Strain based conflict

Terjadi pada saat tekanan dari salah satu peran mempengaruhi kinerja peran lainnya.

c. Behavior based conflict

Berhubungan dengan ketidaksesuaian antara pola perilaku dengan kedua bagian (pekerjaan atau individu).

\section{Ambiguitas Peran}

Ambiguitas peran (role ambiguity) adalah tidak adanya informasi yang memadai yang diperlukan seseorang untuk menjalankan perannya dengan cara yang memuaskan (Khan dalam Agustina, 2009) ${ }^{[1]}$. Rebele dan Michaels (dalam Agustina, 2009) ${ }^{[1]}$ menyatakan bahwa ketidakjelasan peran (role ambiguity) mengacu pada kurangnya kejelasan mengenai harapanharapan pekerjaan, metode-metode untuk memenuhi harapan-harapan yang dikenal, dan/atau konsekuensi dari kinerja atau peranan tertentu.

Menurut Yousef (dalam Yasa, 2017) ${ }^{[16]}$ ambiguitas peran merupakan situasi dimana individu tidak memiliki arah yang jelas mengenai harapan akan perannya dalam organisasi.

\section{Indikator Ambiguitas Peran}

Menurut Rizzo dkk (dalam Diniyah, 2016) ${ }^{[4]}$ menjelaskan mengenai indikator-indikator ambiguitas peran sebagai berikut:
a. Mengelola waktu dengan tidak baik.
b. Tidak mampu bertanggung jawab pada pekerjaan.
c. Tidak memiliki tujuan dan sasaran pekerjaan.
d. Tidak memahami apa yang diinginkan.

\section{HIPOTESIS}

Hipotesis yang diajukan dalam penelitian ini adalah terdapat hubungan antara konflik peran dan ambiguitas peran dengan kinerja perawat wanita di RSUD Sungai Dareh Dharmasraya. Jika konflik peran dan ambiguitas peran tinggi maka kinerja semakin baik dan sebaliknya jika konflik peran dan ambiguitas peran rendah maka kinerja semakin buruk.

\section{METODE PENELITIAN. \\ Indentifikasi Variabel Penelitian}

Menurut Sugiyono (2014) ${ }^{[14]}$ variabel penelitian adalah suatu atribut atau sifat atau nilai dari orang, objek atau kegiatan yang mempunyai variasi tertentu yang ditetapkan oleh peneliti untuk dipelajari dan kemudian ditarik kesimpulannya. Adapun variabel yang diukur dalam penelitian ini adalah sebagai berikut:
1. Variabel bebas
: Konflik Peran $\left(\mathrm{X}_{1}\right)$
Ambiguitas Peran $\left(\mathrm{X}_{2}\right)$
2. Variabel terikat
: Kinerja (Y) 


\section{Definisi Operasional Veriabel Penelitian}

Definisi operasional adalah suatu definisi mengenai variabel yang dirumuskan berdasarkan karakteristik-karakteristik yang dapat dimengerti (Azwar, 2014) ${ }^{[2]}$. Definisi operasional konflik peran adalah adanya ketidaksesuaian peran atau tuntutan peran yang saling bertentangan (tidak konsisten) dalam waktu yang bersamaan, baik dalam satu peran (peran pekerjaan) ataupun dalam dua peran yang tidak berkaitan (peran pekerjaan dan peran keluarga). Definisi operasional ambiguitas peran adalah keadaan dimana seseorang memiliki harapan peran yang tidak jelas dan merasa tidak mampu memprediksi hasil dari perilaku. Ambiguitas peran dapat terjadi pada individu ketika kurangnya informasi yang didapatkan dalam menyelesaikan tugas-tugasnya sehingga menimbulkan ketidakjelasan peran dalam pekerjaan dan sasaran akhirnya mengarah pada ketidakmampuan untuk menyelesaikan tugas-tugas dalam pekerjaannya. Definisi operasional kinerja adalah perwujudan atas pekerjaannya yang telah dihasilkan atau diemban pegawai. Hasil tersebut tercatat dengan baik sehingga tingkat ketercapaian kinerja yang seharusnya dan hal-hal yang terjadi dapat dievaluasi dengan baik. Kinerja merupakan keberhasilan yang dicapai oleh seorang pegawai dalam suatu tugasnya sesuai dengan tanggung jawab yang diberikan kepadanya.

\section{Populasi dan Sampel}

Populasi adalah wilayah generalisasi yang terdiri atas objek atau subjek yang mempunyai kualitas dan karakteristik tertentu yang ditetapkan peneliti untuk dipelajari dan kemudian ditarik kesimpulannya (Sugiyono, 2014) ${ }^{[14]}$.Populasi pada penelitian ini adalah 70 perawat wanita di RSUD Sungai Dareh Dharmasraya.

Teknik pengambilan sampel yang digunakan dalam penelitian ini adalah sampling jenuh. Teknik sampling jenuh adalah teknik penentuan sampel bila semua anggota populasi digunakan sebagai sampel (Sugiyono, 2014) ${ }^{[14]}$. Sampel dalam penelitian ini adalah perawat wanita di RSUD Sungai Dareh Dharmasraya yang berjumlah 70 orang.

\section{Teknik Pengambilan Data}

\section{Alat ukur}

Menurut Azwar (2014) ${ }^{[2]}$ skala sebagai alat ukur dalam psikologi memiliki karakteristik khusus yang membedakannya dari berbagai bentuk pengumpulan data yang lain seperti angket (questionnaire), daftar isian, inventori. Bentuk skala yang digunakan menggunakan empat alternatif jawaban, yaitu SS (Sangat Setuju), S (Setuju), TS (Tidak Setuju), STS (Sangat Tidak Setuju). Peneliti tidak menggunakan pilihan jawaban tengah "N" (Netral).

\section{Skala Kinerja}

Skala kinerja disusun berdasarkan dimensi-dimensi yang dikemukakan Wirawan (2009) ${ }^{[15]}$, dimensi kinerja pegawai menjadi tiga diantaranya hasil kerja, perilaku kerja, dan sifat pribadi yang ada hubungannya dengan pekerjaan.

\section{Skala Konflik Peran}

Skala konflik peran disusun berdasarkan indikator-indikator yang dikemukakan Yang dkk (dalam Junita, 2011) ${ }^{[7]}$, mengemukakan tiga indikator konflik peran diantaranya time based conflict, strain based conflict, dan behavior based conflict.

\section{Skala Ambiguitas Peran}

Skala ambiguitas peran disusun berdasarkan indikator-indikator yang dikemukakan Rizzo (dalam Diniyah, 2016) ${ }^{[4]}$, adanya empat indikator ambiguitas peran diantaranya mengelola waktu dengan tidak baik, tidak mampu bertanggung jawab pada pekerjaan, tidak memiliki tujuan dan sasaran pekerjaan, dan tidak memahami apa yang diinginkan.

\section{Uji Coba Alat Ukur}




\section{Uji Validitas}

Validitas berasal dari kata validity yang mempunyai arti sejauh mana ketepatan dan kecermatan suatu alat ukur dalam melakukan fungsi ukurnya (Azwar, 2014) ${ }^{[2]}$. Suatu data dapat dianggap valid jika berkorelasi signifikan terhadap skor total atau jika melakukan penilaian langsung terhadap koefisien korelasi bisa digunakan batas nilai berkriteria $r_{x y} \geq 0,3$ (Priyatno, $2008)^{[12]}$. Data skala dikatakan valid jika koefisien korelasi lebih besar atau sama dengan 0,3 $\left(\mathrm{r}_{\mathrm{xy}}\right.$ $\geq 0,3$ ) dan sebaliknya aitem skala dikatakan gugur jika koefisien korelasi lebih kecil dari 0,3 $\left(\mathrm{r}_{\mathrm{xy}}<0,3\right)$. Koefesien validitas skala kinerja diperoleh hasil dari jumlah item awal 30 pernyataan, gugur 2 item sehingga jumlah item yang memiliki daya diskriminasi tinggi adalah 28 pernyataan, dengan nilai corrected item-total correlation berkisar antara 0,381 sampai dengan 0,774. Koefisien validitas skala konflik peran diperoleh hasil dari jumlah item awal 30 pernyataan, gugur 3 item sehingga jumlah item yang memiliki daya diskriminasi tinggi adalah 27 pernyataan, dengan nilai corrected item-total correlation berkisar antara 0,405 sampai dengan 0,817 . Koefisien validitas skala ambiguitas peran diperoleh hasil dari jumlah aitem awal 32 pernyataan, seluruh item memiliki daya diskriminasi yang tinggi, dengan nilai corrected item-total correlation berkisar antara 0,349 sampai dengan 0,905 .

\section{Uji Reabilitas}

Reliabilitas sebenarnya mengacu kepada konsistensi atau keterpercayaan hasil ukur, yang mengandung makna kecermatan pengukuran. Pengukuran yang tidak cermat berarti juga tidak akan konsisten dari waktu kewaktu (Azwar, 2014) ${ }^{[2]}$. Koefisien reliabilitas berada dalam rentang angka dari 0 sampai dengan 1,00. Sekalipun bila koefisien reliabilitas semakin tinggi mendekati angka 1,00 berarti pengukuran semakin reliabel (Azwar, 2014) ${ }^{[2]}$. Sebaliknya koefesien yang semakin rendah mendekati 0 berarti semakin rendahnya reliabilitas. Reliabilitas skala kinerja pada penelitian ini menggunakan teknik analisis Alpha Cronbach. Setelah melalui proses penghitungan hasil try out, maka pada skala diperoleh nilai koefisien reliabilitas sebesar 0,943, sedangkan uji reliabilitas pada skala konflik peran melalui teknik analisis Alpha Cronbach diperoleh koefisien sebesar 0,945, dan uji reliabilitas pada skala ambiguitas peran melalui teknik analisis Alpha Cronbach diperoleh koefisien sebesar 0,971. Hal ini menunjukkan bahwa alat ukur skala kinerja, konflik peran, dan ambiguitas peran memiliki reliabilitas yang tinggi.

\section{Uji Coba Alat Ukur Penelitian}

Peneliti terlebih dahulu melakukan uji coba atau try out yang bertujuan untuk menyeleksi item-item mana yang dapat digunakan dalam penelitian sesungguhnya. Uji coba alat ukur penelitian dilakukan pada tanggal 21 Desember 2018 kepada 30 perawat wanita di RSUD Muhammad Zein Painan.

\section{Pelaksanaan Penelitian}

Sampel penelitian ini adalah perawat wanita di RSUD Sungai Dareh Dharmasraya yang berjumlah 70 orang.

\section{Uji Normalitas}

Uji normalitas dalam penelitian ini menggunakan uji Kolmogorov-Smirnov. Priyatno (2008) $)^{[12]}$ menyatakan bahwa data yang dinyatakan terdistribusi normal jika signifikansi (p) lebih besar dari 0,05. Berdasarkan hasil pengolahan data dengan menggunakan program IBM SPSS 21.0, maka diperoleh hasil sebagai berikut:

Nilai signifikansi pada skala Konflik Peran sebesar $\mathrm{p}=0,340$ dengan KSZ $=0,940$ hasil tersebut menunjukan bahwa nilai $\mathrm{p}>0,05$, artinya sebaran skala Konflik Peran terdistribusi secara normal, sedangkan untuk skala Ambiguitas Peran diperoleh nilai signifikansi sebesar $\mathrm{p}=0,170$ dengan $\mathrm{KSZ}=1,110$, hasil tersebut menunjukan bahwa nilai $\mathrm{p}$ $>0,05$, artinya sebaran skala Ambiguitas Peran terdistribusi secara normal. Serta untuk skala 
Kinerja diperoleh nilai signifikasi sebesar $\mathrm{p}=0,085$ dengan $\mathrm{KSZ}=1,256$, hasil tersebut menunjukkan bahwa nilai $\mathrm{p}>0,05$, artinya sebaran skala Kinerja terdistribusi secara normal.

\section{Uji Linieritas}

Uji linieritas bertujuan untuk mengetahui apakah dua variabel mempunyai hubungan yang linier atau tidak. Dua variabel dikatakan mempunyai hubungan yang linier bila signifikansi (Linearity) kurang dari 0,05 (Priyatno, 2008) ${ }^{[12]}$. Berdasarkan hasil pengolahan data dengan menggunakan program IBM SPSS 21.0, maka diperoleh hasil sebagai berikut:

Tabel 1. Uji Linieritas Skala Konflik Peran dengan Kinerja

\begin{tabular}{|c|c|c|c|c|}
\hline $\mathbf{N}$ & Df & Mean Square & F & Sig \\
\hline 70 & 1 & 220,617 & 17,595 & 0,000 \\
\hline
\end{tabular}

Nilai $F=17,595$ dengan signifikasi sebesar $p=0,000(p<0,05)$, artinya varians pada skala konflik peran dengan kinerja tergolong linier.

Tabel 2. Uji Linieritas Skala Ambiguitas Peran dengan Kinerja

\begin{tabular}{|c|c|c|c|c|}
\hline $\mathbf{N}$ & $\mathbf{D f}$ & Mean Square & $\mathbf{F}$ & Sig \\
\hline 70 & 1 & 110,107 & 6,868 & 0,011 \\
\hline
\end{tabular}

Nilai $F=6,868$ dengan signifikasi sebesar $p=0,011(p<0,05)$, artinya varians pada skala ambiguitas peran dengan kinerja tergolong linier.

\section{Uji Hipotesis}

Pengolahan data penelitian tentang hubungan antara konflik peran dan ambiguitas peran dengan kinerja kepada 70 perawat wanita di RSUD Sungai Dareh Dharmasraya menggunakan uji statistic Pearson Product Moment dan Korelasi Ganda dengan bantuan program IBM SPSS 21.0, dapat dilihat pada table berikut:

Tabel 3. Hasil Uji Korelasi Antara Skala Konflik Peran dengan Kinerja

\begin{tabular}{|c|c|c|c|l|}
\hline $\mathbf{P}$ & $(\boldsymbol{\alpha})$ & Nilai Korelasi (r) & R square & \multicolumn{1}{|c|}{ Kesimpulan } \\
\hline 0,000 & 0.01 & $-0,439$ & 0,193 & $\begin{array}{l}\text { Sig (2-tailed) 0,000 < 0,01 level } \\
\text { signifikan (a) berarti hipotesis } \\
\text { diterima }\end{array}$ \\
\hline
\end{tabular}

Berdasarkan hasil uji diatas maka diperoleh koefisien korelasi antara variabel Konflik Peran dengan Kinerja yaitu sebesar $r=-0,439$ dengan taraf signifikansi $p=0,000$. Hal ini menunjukkan adanya korelasi yang berarah negatif, yang artinya jika Konflik Peran tinggi, maka Kinerja pada perawat wanita di RSUD Sungai Dareh Dharmasraya akan rendah, sebaliknya jika Konflik Peran rendah, maka Kinerja pada perawat wanita di RSUD Sungai Dareh Dharmasraya akan tinggi. Hal ini diperkuat dengan hasil uji signifikansi dengan bantuan IBM SPSS versi 21.0, didapatkan $\mathrm{p}=0,000<0,01$ level of significant $(\alpha)$, sesuai dengan pernyataan Nugroho (dalam Efandi, 2018) ${ }^{[5]}$ hipotesis diterima, bahwa terdapat hubungan antara Konflik Peran dengan Kinerja perawat wanita di RSUD Sungai Dareh Dharmasraya.

Tabel 5. Hasil Uji Korelasi Antara Skala Ambiguitas Peran dengan Kinerja

\begin{tabular}{|c|c|c|c|l|}
\hline $\mathbf{P}$ & $(\boldsymbol{\alpha})$ & NilaiKorelasi (r) & R square & \multicolumn{1}{|c|}{ Kesimpulan } \\
\hline 0,009 & 0.01 & $-0,310$ & 0,096 & $\begin{array}{l}\text { Sig (2-tailed) 0,009<0,01 level } \\
\text { signifikan (a) berarti hipotesis } \\
\text { diterima }\end{array}$ \\
\hline
\end{tabular}

Berdasarkan hasil uji korelasi di atas, maka diperoleh koefisien korelasi antara variabel Ambiguitas Peran dengan Kinerja yaitu sebesar $r=-0,310$ dengan taraf signifikansi $\mathrm{p}=0,009$. Hal ini menunjukkan adanya korelasi yang berarah negatif, yang artinya jika Ambiguitas Peran tinggi, maka Kinerja pada perawat wanita di RSUD Sungai Dareh Dharmasraya akan rendah, sebaliknya jika Ambiguitas Peran rendah, maka Kinerja pada 
perawat wanita di RSUD Sungai Dareh Dharmasraya akan tinggi. Hal ini diperkuat dengan hasil uji signifikansi dengan bantuan IBM SPSS versi 21.0, didapatkan $\mathrm{p}=0,009<0,01$ level of significant $(\alpha)$, sesuai dengan pernyataan Nugroho (dalam Efandi, 2018) ${ }^{[5]}$ hipotesis diterima, bahwa terdapat hubungan antara Ambiguitas Peran dengan Kinerja perawat wanita di RSUD Sungai Dareh Dharmasraya.

Tabel 6. Hasil Uji Korelasi Antara Konflik Peran dan Ambiguitas Peran dengan Kinerja

\begin{tabular}{|c|c|c|c|c|}
\hline \multirow{2}{*}{$\mathbf{R}$} & \multirow{2}{*}{ R Square } & \multicolumn{3}{|c|}{ Change Statistics } \\
\cline { 3 - 5 } & & R Square Change & F Change & Sig. F Change \\
\hline 0,461 & 0,213 & 0,213 & 9,004 & 0,000 \\
\hline
\end{tabular}

Berdasarkan hasil uji korelasi diatas, diperoleh nilai koefisien korelasi R sebesar 0,461 dengan nilai probabilitas (sig. F change) $=0,000$. Karena nilai sig. F change $<0,05$, maka keputusannya adalah hipotesis diterima artinya Konflik Peran dan Ambiguitas Peran secara bersamaan dan signifikan terhadap Kinerja perawat wanita di RSUD Sungai Dareh Dharmasraya.

Berikut tabel deskriptif statisitik dari variabel konflik peran, ambiguitas peran, dan kinerja berdasarkan mean empirik sebagai berikut:

Tabel 7. Descriptive Statistic Skala Konflik Peran, Ambiguitas Peran, dan Kinerja

\begin{tabular}{|c|c|c|c|c|c|}
\hline \multirow{2}{*}{ Variabel } & \multirow{2}{*}{$\mathbf{N}$} & \multicolumn{5}{|c|}{ Empirik } \\
\cline { 3 - 6 } & & Mean & Std. Deviation & Minimum & Maximum \\
\hline Konflik Peran & 70 & 106,60 & 2,981 & 81 & 97 \\
\hline Ambiguitas Peran & 70 & 91,01 & 4,477 & 92 & 114 \\
\hline Kinerja & 70 & 46,74 & 4,071 & 38 & 64 \\
\hline
\end{tabular}

Berdasarkan nilai mean empirik, maka dapat dilakukan pengelompokkan yang mengacu pada kriteria pengkategorisasian dengan tujuan menempatkan individu kedalam kelompok-kelompok yang terpisah secara berjenjang menurut suatu kontinum berdasarkan atribut yang diukur (Azwar, 2018) ${ }^{[3]}$ dengan ketentuan sebagai berikut :

Tabel 8. Norma Kategorisasi

\begin{tabular}{|c|c|}
\hline Norma & Kategorisasi \\
\hline$X<(\mu-1,0 \sigma)$ & Rendah \\
\hline$(\mu-1,0 \sigma) \leq X<(\mu+1,0 \sigma)$ & Sedang \\
\hline$(\mu+1,0 \sigma) \leq X$ & Tinggi \\
\hline
\end{tabular}

Keterangan:

$\sigma=$ standardeviasi

$\mathrm{X}=$ raw score

$\mu=$ rata-rata

Berdasarkan uraian tabel di atas, maka diperoleh kategorisasi subjek penelitian pada variable Konflik Peran, Ambiguitas Peran, dan Kinerja sebagai berikut:

Tabel 9. Pengelompokkan Kategorisasi Subjek

\begin{tabular}{|c|c|c|c|c|}
\hline Variabel & Skor & Jumlah & Persentase (\%) & Kategori \\
\hline \multirow{3}{*}{$\begin{array}{c}\text { Konflik } \\
\text { Peran }\end{array}$} & $81-87$ & 7 & $10 \%$ & Rendah \\
\cline { 2 - 5 } & $88-93$ & 49 & $70 \%$ & Sedang \\
\cline { 2 - 5 } & $94-97$ & 14 & $20 \%$ & Tinggi \\
\hline \multirow{2}{*}{$\begin{array}{c}\text { Ambiguitas } \\
\text { Peran }\end{array}$} & $92-101$ & 8 & $11 \%$ & Rendah \\
\cline { 2 - 5 } & $102-110$ & 49 & $70 \%$ & Sedang \\
\hline \multicolumn{4}{|c}{ Jurnal PSYCHE 165 Vol 12 no 2(2019) 124-133 } \\
\hline
\end{tabular}




\begin{tabular}{|c|c|c|c|c|}
\hline \multirow{3}{*}{ Kinerja } & $111-114$ & 13 & $18 \%$ & Tinggi \\
\cline { 2 - 5 } & $38-42$ & 9 & $13 \%$ & Rendah \\
\cline { 2 - 5 } & $43-50$ & 52 & $74 \%$ & Sedang \\
\cline { 2 - 5 } & $51-64$ & 9 & $13 \%$ & Tinggi \\
\hline
\end{tabular}

Berdasarkan tabel 9 di atas dapat digambarkan 7 orang $(10 \%)$ perawat wanita di RSUD Sungai Dareh Dharmasraya memiliki konflik peran yang rendah, 49 orang (70\%) perawat wanita di RSUD Sungai Dareh Dharmasraya memiliki konflik peran yang sedang dan 14 orang (20\%) perawat wanita di RSUD Sungai Dareh Dharmasraya memiliki konflik peran yang tinggi. Sementara itu ada 8 orang (11\%) perawat wanita di RSUD Sungai Dareh Dharmasraya memiliki ambiguitas peran yang rendah, 49 orang $(70 \%)$ perawat wanita di RSUD Sungai Dareh Dharmasraya memiliki ambiguitas peran yang sedang dan 13 orang (18\%) perawat wanita di RSUD Sungai Dareh Dharmasraya memiliki ambiguitas peran yang tinggi. Selanjutnya terdapat 9 orang $(13 \%)$ perawat wanita di RSUD Sungai Dareh Dharmasraya memiliki kinerja yang rendah, 52 orang (74\%) perawat wanita di RSUD Sungai Dareh Dharmasraya memiliki kinerja yang sedang dan 9 orang (13\%) perawat wanita di RSUD Sungai Dareh Dharmasraya memiliki kinerja yang tinggi.

\section{Sumbangan Efektif}

Besar sumbangan variabel Konflik Peram terhadap Kinerja, Ambiguitas Peran terhadap Kinerja, serta variabel Konflik Peran dan Ambiguitas Peran secara bersama terhadap Kinerja dapat ditentukan dengan menggunakan rumus koefisien determinan. Koefisien determinan adalah kuadrat dari koefisien korelasi yang dikali dengan $100 \%$ (Nugroho dalam Efandi, 2018) ${ }^{[5]}$. Derajat koefisien determinan dicari dengan menggunakan rumus sebagai berikut:

$$
\mathbf{K P}=\mathbf{r}^{2} .100 \%
$$

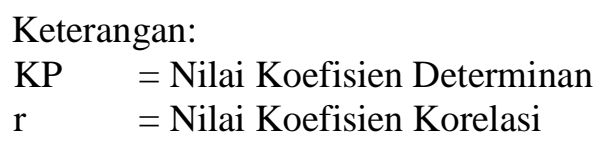

Berdasarkan rumus tersebut maka dapat ditentukan bahwa besarnya sumbangan konflik peran terhadap kinerja adalah sebesar 19\% dan $81 \%$ lagi dipengaruhi oleh faktor lain, sumbangan ambiguitas peran terhadap kinerja adalah sebesar 10\% dan 90\% lagi dipengaruhi oleh faktor lain, serta besarnya sumbangan konflik peran dan ambiguitas peran terhadap kinerja adalah sebesar $21 \%$ dan $79 \%$ lagi dipengaruhi oleh faktor lain.

Berdasarkan hasil uji korelasi Product Moment (Pearson) terhadap variabel konflik peran dan kinerja yang dilakukan dengan bantuan IBM SPSS 21, dimana level of significant $(\alpha)$ 0,01, karena nilai (p) sig 0,000 $<0,01$ dengan nilai korelasi $(\mathrm{r})=-0,439$ maka hipotesis diterima. Selanjutnya hasil uji korelasi Product Moment (Pearson) terhadap variabel ambiguitas peran dan kinerja yang dilakukan dengan bantuan IBM SPSS 21, dimana level of significant $(\alpha)$ 0,01, karena nilai (p) sig 0,009 $<0,01$ dengan nilai korelasi $(\mathrm{r})=-0,310$ maka hipotesis diterima. Serta hasil uji korelasi ganda terhadap variabel konflik peran dan ambiguitas peran dengan kinerja yang dilakukan dengan bantuan IBM SPSS 21, dimana nilai probabilitas (sig $\mathrm{F}$ change $)=0,000$, karena nilai sig. $\mathrm{F}$ change $<0,05$ dengan nilai korelasi $(\mathrm{R})=0,461$ maka hipotesis diterima.

\section{Kesimpulan}

Berdasarkan hasil dan pembahasan yang telah dijelaskan, maka dapat ditarik kesimpulan yang sekaligus merupakan jawaban dari tujuan penelitian yaitu Terdapat hubungan antara konflik peran dengan kinerja pada perawat wanita di RSUD Sungai Dareh dengan arah negatif, artinya jika konflik peran tinggi, maka kinerja pada perawat wanita di RSUD Sungai 
Dareh akan rendah, sebaliknya jika konflik peran rendah, maka kinerja pada perawat wanita di RSUD Sungai Dareh akan semakin tinggi. Terdapat hubungan antara ambiguitas peran dengan kinerja pada perawat wanita di RSUD Sungai Dareh dengan arah negatif, artinya jika ambiguitas peran tinggi, maka kinerja pada perawat wanita di RSUD Sungai Dareh akan rendah, sebaliknya jika ambiguitas peran rendah, maka kinerja pada perawat wanita di RSUD Sungai Dareh akan semakin tinggi. Terdapat hubungan antara konflik peran dan ambiguitas peran dengan kinerja pada perawat wanita di RSUD Sungai Dareh dengan arah negatif, artinya jika konflik peran dan ambiguitas peran tinggi, maka kinerja pada perawat wanita di RSUD Sungai Dareh akan rendah, sebaliknya jika konflik peran dan ambiguitas peran rendah, maka kinerja pada perawat wanita di RSUD Sungai Dareh akan semakin tinggi. Adapun sumbangan efektif dari variabel konflik peran terhadap kinerja sebesar 19\%, sumbangan efektif dari variabel ambiguitas peran terhadap kinerja sebesar $10 \%$ dan sumbangan efektif dari variabel konflik peran dan ambiguitas peran terhadap kinerja sebesar $21 \%$.

\section{Daftar Pustaka}

[1]Agustina, Lidya. 2009. "Pengaruh Konflik Peran, Ketidakjelasan Peran, dan Kelebihan Pera terhadap Kepuasan Kerja dan Kinerja Auditor". Jurnal Akutansi.

[2]Azwar, Saifudin (2014). Penyusunan Skala Psikologi. Yogyakarta: Pustaka Belajar.

[3]Azwar, Saifudin (2018). Metode Penelitian. Yogyakarta: Pustaka Belajar.

[4]Diniyah, Nur Muharrikati. 2016. "Pengaruh Konflik Peran, Ambiguitas Peran dan Psychological Capital terhadap Stres Kerja pada Perawat”. Skripsi. Fakultas Psikologi Universitas Islam Negeri Syarif Hidayatullah Jakarta.

[5]Efandi, Satria. 2018. "Hubungan Antara Self-Esteem dan Dukungan Sosial dengan Orientasi Masa Depan Siswi UPTD PSBR Harapan Padang Panjang”. Skrpsi. Fakultas Psikologi Universitas Putra Indonesia "YPTK" Padang.

[6]Ekawarna. 2018. Manajemen Konflik dan Stres. Jakarta: Bumi Aksara.

[7]Junita, Audi. 2011. "Konflik Peran Sebagai Salah Satu Pemicu Stres Kerja Wanita Karir”. Jurnal Keuangan dan Bisnis.

[8]Kumajas, Fisella dkk. 2008. "Hubungan Karakteristik Individu dengan Kinerja Perawat di Ruang Inap Penyakit Dalam RSUD Datoe Binangkang Kabupaten Bolalang”. Jurnal keperawatan.

[9]Lumingkewas, Mega. 2015. "Hubungan Kondisi Kerja dengan Stres Kerja Perawat di Ruangan Instalansi Gawat Darurat Medik RSUP Prof. Dr. R.D. Kandou Manado”. Jurnal keperawatan.

[10]Nur, Ismi dkk. 2016. "Pengaruh Konflik Peran, Ambiguitas Peran dan Stres Kerja terhadap Kinerja Karyawan". Jurnal Manajemen.

[11]Priansa, Donni. 2017. Manajemen Kinerja Pegawai dalam Pengelolaan SDM Perusahaan. Bandung: CV Pustaka Setia.

[12]Priyatno, Dwi. 2008. Mandiri Belajar SPSS. Yogyakarta: Mediakom.

[13]Sorongan, Marlin dkk. 2015. "Konflik Peran dan Ambiguitas Peran terhadap Kinerja Karyawan pada PT. Bank Tabungan Pensiunan Nasional (BTPN) TBK Cabang Manado”. Jurnal Ekonomi dan Bisnis.

[14]Sugiyono (2014). Metode Penelitian Kuantitatif, Kualitatif, dan R\&D. Bandung: CV. Alfabeta.

[15]Wirawan. 2009. Evaluasi Kinerja Sumber Daya Manusia. Jakarta: Salemba Empat.

[16]Yasa, Murdana. 2017. "Pengaruh Konflik Peran dan Ambiguitas Peran terhadap Kinerja Pegawai Melalui Mediasi Stres Kerja pada Dinas Kesehatan Kota Denpasar Bali”. Jurrnal Ekonomi Dan Bisnis. 